Article

\title{
How Business Idea Fit Affects Sustainability and Creates Opportunities for Value Co-Creation in Nascent Firms
}

\author{
Gian Luca Casali ${ }^{1, *}$, Mirko Perano ${ }^{2, *}$ (D) , Andrea Moretta Tartaglione ${ }^{3}$ and Roxanne Zolin ${ }^{4}$ \\ 1 School of Management, Queensland University of Technology, Brisbane City QLD 4000, Australia \\ 2 Department of Management, Reald University College, Vlorë 9400, Albania \\ 3 Department of Economics and Law, University of Cassino and Southern Lazio, Cassino FR 03043, Italy; \\ a.moretta@unicas.it \\ 4 Australian Institute of Business, Adelaide SA 5000, Australia; roxanne.zolin@gmail.com \\ * Correspondence: luca.casali@qut.edu.au (G.L.C.); mperano@asar.edu.al (M.P.); Tel.: +61-731385096 (G.L.C.)
}

Received: 25 November 2017; Accepted: 10 January 2018; Published: 14 January 2018

\begin{abstract}
A well-defined business idea is essential for nascent business sustainability in the future. The business idea must fit firm knowledge and resources to a profitable business opportunity. This work adopts the framework of value co-creation, strongly related to the service-dominant logic paradigm. We ask how does business idea fit affect new venture sustainability and create opportunities for value co-creation. We propose that a business idea that lacks fit is less sustainable, but it could create opportunities for value co-creation. This study develops and validates an empirically grounded taxonomy of business idea fit based on 729 Australian nascent firms using quantitative data generated from the results of a large study called CAUSEE (Comprehensive Australian Study of Entrepreneurial Emergence). A cluster analysis is used to identify distinct patterns of business idea fit. The empirical taxonomy developed in this study found four distinct clusters of firms, which were distinguished by the fit of their new business idea to knowledge, resources and market profitability: very good fit, low knowledge fit, low profit fit and low fit. Results show how these different patterns of fit create opportunities for value co-creation to create business future sustainability.
\end{abstract}

Keywords: business idea; nascent business sustainability; value co-creation; S-D logic

\section{Introduction}

What could be more important to a new firm than the sustainability of a new business idea?

Business ideas are created to cover gaps (grey areas) consisting of problems derived from needs partially or not yet fully satisfied. Such needs may have different nature, i.e., while related to consumers, production of goods, or provision of services, they may also be social. Organizations, born from such business ideas, capture these grey areas, considering them as opportunities. As stated by Porter.

"Businesses create shared value when they can make a profit-create economic value-while simultaneously meeting important social needs or important social goals like improving environmental performance, reducing problems of health, improving nutrition, reducing disability, improving safety, and helping people save for retirement. The basic idea of shared value is that there are many opportunities in meeting these societal needs to actually create economic value in the process. Shared value is where you do both." [1] (p. 423) 
The literature over time states that the aim of (nascent) firms is to create social and economic value [2,3] (p. 167), [4] (p. 64), [1] (p. 421) which regenerates itself over time. In order to satisfy these needs and be competitive in their respective markets, each nascent firm must to be innovative and oriented in both social and market directions. "There can be different intentions behind the development of innovations that can range from business, economic, political, social or militaristic objectives, social innovations often have aims that draw on notions of contributing to the welfare of society and improving social capital" [5] (p. 15). The social innovations are "distinguished by alliance between creative individuals with ideas and energy, on the one hand, and institutions with power and money to make those changes a reality on the other" [6] (p. 364). According to the EU's orientation on the topics of internal market, industry, entrepreneurship and SME innovation policies, social innovation can be defined as "new ideas that meet social needs, create social relationships and form new collaboration" [7]. Therefore, the establishment of an organization can be seen as a bilateral flow that starts from an idea generated to satisfy an economic or social need across multiple industries and that creates (or co-creates) value back to the origin point.

The literature provides different definitions of sustainability under different lenses. Hopwood et al. [8], describe sustainability as the result of a growing awareness of global environment and socio-economic problems. Elkington, $[9,10]$ coined the triple bottom line (TBL) term as a concept that underlined transversal and multidisciplinary perspectives. The author suggests that the growth of a firm is determined by a balance between economic health, social equity and environmental eligibility on the one hand, and on the other hand entrepreneurial behavior [11].

Hawken [12] (p. 139) defines sustainability as an "economic state where the demands placed upon the environment by people and commerce can be met without reducing the capacity of the environment to provide for future generations". Viedermian's interpretation of sustainability is a participatory process that promotes a vision of a community that both respects and make prudent use of all its resources (natural, human, human-created, social, cultural, scientific, etc.) with the final goal of attaining a high degree of economic security, while maintaining the ecological system [13] (p. 471).

Despite the fact that there are many definitions of sustainability, they all have in common the necessity to preserve resources or at least to use them parsimoniously. Consequently, we used this common point to argue that venture failure can be seen as resources that are either lost or not used at their best.

Therefore, the main aim of this study is to promote nascent firm survival and its long term sustainability. All nascent firms begin with the efforts provided by the person/entrepreneur in creating his/her business idea, which is also the main purpose of this study.

At the same time, to be sustainable a business idea should ensure the profitability of the nascent firm through its capability to survive over time by creating and capturing social, economic and/or environmental value and by satisfying the expectations and needs of the relevant actors in its context, such as stakeholders.

In this paper we refer to sustainability in the context of nascent firms and therefore as the opportunity for a firm to became sustainable in the future. Therefore, having a well-defined business idea is an essential pillar for the development of sustainability over the lifetime of the firm. In order to become a firm, the business idea must have "relatedness", or fit to firm knowledge and resources [14] in order to capture (through the business idea) the profitability of the business opportunities [15]. The achievement of these results is strongly related to important issues such as market profitability and the knowledge and resources the founder has access to. Based on these considerations, this paper makes a connection between the overall business idea fit relating to these three elements, which can create the framework for value co-creation. In other words, a business idea that is not closely related to either market profitability, knowledge or resources is less sustainable but it can create an opportunity for value co-creation.

According to the service-dominant logic (S-D logic) $[16,17]$ perspective, value co-creation can be defined as an activity that takes place between economic and social actors interacting and exchanging 
resources and competences within and across networks [17]. S-D logic represents the transition from a goods-dominant, "inside-out", value chain paradigm towards a knowledge intensive, collaborative, resource integrating, value network paradigm [18]. A S-D logic perspective translates the goods (as "Distribution Mechanism for Service Provision") [16] logic into service logic, that therefore becomes dominant; so, "even when goods are involved, what is driving economy activity is service-applied knowledge" [17]. Therefore, the concept of value co-creation under the S-D logic perspective fits this context, in that a business idea aimed both at the production of goods and service, considers the goods as a "distribution mechanism for service provision" [16,17,19]. In this new logic, networks and partnerships have a great influence on the value co-creation of a company and must therefore be taken into consideration as part of the business idea [20-22]. The literature on value co-creation states that the business idea should be externally oriented and address questions like: how to connect with factor and product markets; which parties to link to the focal actors, what exchange mechanism to adopt; what resources and capabilities to deploy to enable exchange of goods or information; and how to control the interactions $[23,24]$ (p. 53).

Hence, the effectiveness of a business idea in value co-creation is defined by the internal configurational fit between all business model elements and the external configurational fit between the provider's business model and those of customers, suppliers and other business partners [20].

Despite the fact that new venture idea characteristics and creation is a vital element in the entrepreneurial literature [14], to date there has been limited research attention to how the business idea relates to important issues such as market, resources and knowledge. Semasinghe et al. [25] found that the new venture idea has an important role in the venture creation process, as reflected in the individual/opportunity nexus proposed by Shane and Venktaraman [26]. Particularly, it was found that characteristics of the venture idea like novelty, knowledge relatedness and resource relatedness are key enablers for its attractiveness [27].

Some researchers show the relatedness of business ideas to pre-existing companies in mergers, acquisitions and spinoffs [28-32], where relatedness typically refers to multidimensional forms of synergy between the parent and target firm. However, Davidsson [14] noted that little has been done regarding assessing business idea fit with the owner's knowledge [33-35], or the owner's resources, [36] to investigate the consequences of business idea fit [37].

Hence, we ask how does business idea fit affect new venture sustainability and create opportunities for value co-creation.

This work aims to identify distinct clusters of owners with specific patterns of business idea fit, which create opportunities for value co-creation leading towards sustainability. The analysis shows how different clusters of owners with patterns of fit can lead firms to create and change their business idea, and which cluster's pattern of idea fit is most successful in getting the business started. In this preliminary study, a taxonomy of nascent firms is created based upon three factors identified in the data: resource relatedness, market profitability relatedness and knowledge relatedness. These factors are used to identify clusters of firms with similar ratings. The taxonomy clusters allow us to see if these clusters operate in a similar fashion with respect to business idea changes and success in starting the new venture.

The paper is organized as follows. First, a theoretical background of business idea fit based on the value co-creation literature is provided. Second, the taxonomy methodology and process used in the analysis is described and the results and discussion are outlined. The last section provides a conclusion to answer the research questions.

\section{Business Idea Fit}

One of the business idea core concepts was provided by Normann [38,39]. The author framed three components of a business idea: (1) the external environment; (2) the offering of the company and (3) the internal factors such as organization structure, resources, knowledge and capabilities, systems, values. This concept highlights that "the relation to the external environment depends on 
the offering, which in turn is dependent upon firm-internal factors" [40]. A business idea is good if the idea is sustainable as the foundation for a real business, where sustainability represents resiliency over time. While the characteristics of the new business owner are important, they are not the only consideration in crafting a new business idea. The evolution of value creation, from value creation by the manufacturing firm to value co-creation in a network, necessitates a corresponding change in the concepts used to depict the business idea.

A comprehensive business idea framework should illustrate the resource and capability base of the nascent firm. However, the paradigm of value co-creation indicates that the business idea construct should also be externally oriented and illuminate the relationships that the firm has with the various actors in its value network [18]. In this view, the business idea concept should be a general construct explaining how a firm will interact with suppliers, customers and partners [41]. A firm oriented to value co-creation should start from a business idea that has a high degree of internal and external configurational fit, where external configurational fit connotes the compatibility of the firm's business idea with its customers, suppliers and other business partners. According to Nenonen and Storbacka [18] (p. 11) a "higher degree of external configurational fit can be achieved both by modifying the firm's own business model and by altering the firm's customer, supplier and partner portfolios".

Central elements in value co-creation are resources, knowledge and interactions with customers. In fact, S-D logic [16,17] proposes that value is co-created as actors interact to apply resources and exchange knowledge [42]. Sustainable value can be created only when the firm and customers' need and objectives fit, so a deep understanding of customers and their participation to the value creation process can generate solid financial results. Therefore, a business idea is consistent with market profitability only when it "fits the firm and its customers" [18]. In the following sections, we analyze relatedness, which is defined as the contextual fit between knowledge, resources and the new business idea [14]. Another aspect of relatedness is the match between the new business idea and the profitability of the business opportunity. Thus, we propose that the business idea fit is the combined fit of the new business idea to the relatedness of the market profitability, knowledge and resources of the owner's value network.

\subsection{Knowledge Relatedness}

Knowledge is defined by Bollinger and Smith [43] (p. 9) as "the understanding, awareness, or familiarity acquired through study, investigation, observation, or experience over the course of time". More specifically, firm knowledge is defined as what people in the firm know about customers, products, processes, mistakes, and successes [43].

The most valuable business ideas are those for which firms have an informational advantage [33]. According to Berger and Luckmann [44], all knowledge is developed, transmitted, and maintained in social situations. S-D logic suggests that firms can achieve the desirable position of offering efficient and effective marketplace solutions by absorbing knowledge from the environment, customers and value networks [45,46]. Organizations that learn from customers, employees and their surrounding community are able to be more innovative and adaptive to their environments. The value co-creation process includes actions of reciprocal knowledge exchange between all the actors involved [41] in the articulation and expression of current and future needs [47]. Sharing information from the repositories of accumulated previous learning, ideas, creativity, and real-life situations and roles between the firm and the consumer builds competence in the process and co-creates value [48]. By sharing knowledge with other relevant players, firms can achieve better outcomes than those they would get in isolation due to reconciliation, shared inventiveness, and better expression and evaluation of needs [49-52]. This knowledge sharing leads to integrating perspectives and skills to dynamically co-create value [53].

The association between knowledge and business ideas can be referred to as knowledge relatedness [25]. High levels of knowledge relatedness can benefit start-ups and already operating small businesses [54]. Tanriverdi and Venkatraman [55] proposed that corporate performance is improved when the firm simultaneously exploits three types of knowledge relatedness, which are 
product, customer and managerial knowledge relatedness. West and Noel [56] found that knowledge relatedness with respect to the type of business is positively associated with performance. We call the extent to which the business idea aligns with the actors' knowledge relatedness.

\subsection{Resource Relatedness}

The idiosyncratic resource collection of the individual is important in the recognition of the new business idea [57]. Entrepreneurial opportunities exist for individuals primarily because different agents have different beliefs about the relative value of resources, which can be converted from inputs into outputs [27]. Consequently, the nature of the opportunity determines the direction and process for acquiring and assembling resources in a firm [58]. Put another way, the resources of a firm must fit with the opportunity or the resources could be wasted [59].

The value co-creation literature suggests that markets are configurations through which firms deploy and integrate resources to co-create value [17,60-63]. The concept of resource-integrating actors highlights the idea of generic actors that have ownership of, or access to resources [64]. These actors can be viewed as open systems, "effectively depending on the resources of others to survive" [65] (p. 149). The exchange occurs because no single actor has all the necessary resources to operate successfully in isolation [66]. In practice, all stakeholders are resource-integrators that collectively co-create the network's shared value [67]. For this reason, identifying stakeholder motives and establishing the linkages between stakeholder motives and resources is fundamental to boosting the creative potential [68]. S-D logic recognizes two categories of resources: (1) operand resources, which are typically physical; and (2) operant resources, which are typically human, organizational, informational, and relational [69]. Operand resources tend to be static in nature, while operant resources are dynamic and can be rejuvenated and replenished. Therefore, competitive advantage is primarily created through operant resources, rather than through operand resources, because they help solve problems, fulfil needs, and produce a favorable customer experience [16].

In a market context, the business model construct can be seen as the interface through which various actors' resources and capabilities are orchestrated for value co-creation [18]. According to Storbacka et al. [62], market actors negotiate through their business models which aspects of their resource and capability configurations are being used and how these configurations interact for value co-creation. The resources that the individual can share within the value network represent a corridor (or potentially a barrier) to implementing the new business idea, leading to the concept of resource-business-idea relatedness [70]. Thus, the fit between the business idea and the owner's resources is called resource relatedness [25].

\subsection{Market Profitability Relatedness}

Of central importance are the market issues, in particular, does the new business idea fit with the most profitable market opportunities? Organizational decision-making research and the behavioral view of the firm show the importance of considering an opportunity-driven approach [71]. A qualitative study proposes that high performing firms create market fit [72]. A recent study found that the relationship between the use of market research techniques and profit margin is stronger for co-creation techniques than it is for traditional market research techniques [15].

In recent years, a growing body of marketing literature [17,73-75] has focused on the central role played by consumers. Several indicators of market profitability such as sales revenue, return on sales, market and sales growth and market share size depend on customer acquisition, retention and satisfaction. In this view, a deepening knowledge of the potential customers and the interactions with them becomes critical, since the formulation of the business idea helps firms to create a business idea consistent with the needs and requirements of the market segment, i.e., products or services that will be sold. The co-creative paradigm recognizes that consumers, both existing and potential, are prerequisites for the creation of value because they exert a considerable influence on the formulation of the value proposition through the contribution of their own resources, and sometimes by adopting the roles 
of co-diagnoser, co-designers, co-producers, and co-implementers [76] (p. 23). When customers and providers interact, their shared knowledge of reality becomes reinforced because they understand that their respective perceptions of reality are related [77]. Therefore, the active role of customers is critical for the success of the value proposition and they should not be considered simple marketing targets [78]. In other words, taking the market and particularly the potential customers into consideration when designing the business idea should be more profitable. To address this issue, we call the extent to which the business idea reflects market profitability relatedness.

\section{Empirical Taxonomy}

It is important to clarify what a taxonomy is, especially in light of the debate about the difference between the terms taxonomy and typology. Despite a number of scholars suggesting that there is little difference between taxonomies and typologies [79], the literature clearly defines typology as an invention of individual creativity, and taxonomy as an empirical tool for building complex filing systems that allow both the ordering and the retrieval of large amounts of data [80,81]. In other words, a typology is designed by forming priori classes/groups and subsequently placing cases into these groups, whereas the classes/groups in taxonomy emerge from the empirical procedures used to sort cases on the basis of similarity or contrast [81]. It has been widely argued that developing empirical taxonomies can reduce the complexity of empirical phenomena to a few constructs [82-84]. Additionally, constructing a usable taxonomy plays a fundamental role in the development of a scientific body of knowledge [85].

\section{Methodology}

The CAUSEE (Comprehensive Australian Study of Entrepreneurial Emergence) dataset was used to determine the major factors in the data; once the factors were identified a factor analysis was applied. The CAUSEE dataset was collected over a period of five years (2007-2013) from a nationally representative sample of nascent and young entrepreneurs [86]. Nascent firms were identified based on their undertakings in relation to some tangible "start-up behavior" (looking for equipment or business location; or organizing a start-up team) within the last 12 months, and young firm are firms that were already established but less than four years old. The data was collected using CATI (computer-aided telephone interview) with subsequent waves (five in total) with intervals of 12 months from 2007 to 2013. The interviews conducted to qualify respondents were between 40 and 50 minutes. The sample was drawn from the AMSRO (Association of Market and Social Research Organizations) random digit dialing (RDD) telephone resource. The CAUSEE sample was framed and selected using a nationwide sample over 30,105 Australian residential households. This sample was contacted randomly in order to identify both nascent and young firms, as stated earlier. As a result of the CAUSEE project, 1410 respondent were identified as either nascent or young entrepreneurs. For the purpose of this study only the data relevant to nascent firms (729 firms) from the CAUSEE dataset were used in our analysis. This sampling approach and longitudinal study avoids the success bias of not observing firms who fail and leave the sample pool. Based upon the data from the CAUSEE data, a number of potential business idea relatedness activities were used in this study to develop a usable taxonomy that can assist in understanding the differences between young firms and their approaches towards entrepreneurial activities. The business idea relatedness activities adopted in this study include resource relatedness, knowledge relatedness and market profitability relatedness. First, we use these business idea relatedness activities to determine the major factors in the data. Then we use these factors to identify clusters of like firms.

\section{Data Analysis Overview}

Table 1 provides an overview of the descriptive statistics and correlations of the data. It is important to highlight the significant linear associations between the three factors associated with the business idea supporting their adoption in the cluster analysis. 
As shown in Table 1, the educational levels of the nascent entrepreneurs varied from completing high school (28.7\%) to master/doctorate degree (17.9\%) and completing technical colleges (28.7\%) to university degrees (22.4\%). Also, the employment status of the respondents was quite diverse covering self-employees $(49.7 \%)$, employees $(36.6 \%)$, homemakers $(5.9 \%)$, retirees $(2.6 \%)$, students $(2.3 \%)$ and unemployed $(2.5 \%)$.

Table 1. Descriptive statistics and correlations $(\mathrm{N}=729)$.

\begin{tabular}{ccccccccccccc}
\hline & Variables & Mean & Std Dev. & Min. & Max. & $\mathbf{1}$ & $\mathbf{2}$ & $\mathbf{3}$ & $\mathbf{4}$ & $\mathbf{5}$ \\
\hline 1 & Gender & 1.41 & 0.491 & 1 & 2 & 1 & 0.032 & $-0.090^{*}$ & 0.018 & -0.029 & 0.023 \\
2 & Employment Status & 1.91 & 1.065 & 1 & 6 & 0.032 & 1 & $0.100^{* *}$ & -0.037 & -0.011 & 0.009 \\
3 & Education & 3.69 & 1.592 & 1 & 8 & $-0.090^{*}$ & $0.100 * *$ & 1 & 0.001 & 0.065 & -0.047 \\
4 & Resource Relatedness & 4.2561 & 0.8631 & 1 & 5 & 0.018 & -037 & 0.001 & 1 & $0.402^{* *}$ & $0.363 * *$ \\
5 & Profitability Relatedness & 3.9272 & 0.9746 & 1 & 5 & -0.029 & -0.011 & 0.065 & $0.4022^{* *}$ & 1 & $0.264^{* *}$ \\
6 & Knowledge Relatedness & 4.1976 & 0.8006 & 1 & 5 & 0.023 & 0.009 & -0.047 & $0.363^{* *}$ & $0.264^{* *}$ & 1 \\
\hline
\end{tabular}

* Correlation is significant at the 0.05 level (two-tailed); ${ }^{* *}$ Correlation is significant at the 0.01 level (two-tailed).

Figure 1 illustrates the process undertaken to develop and validate the cluster taxonomy. The survey data was analyzed in several ways.

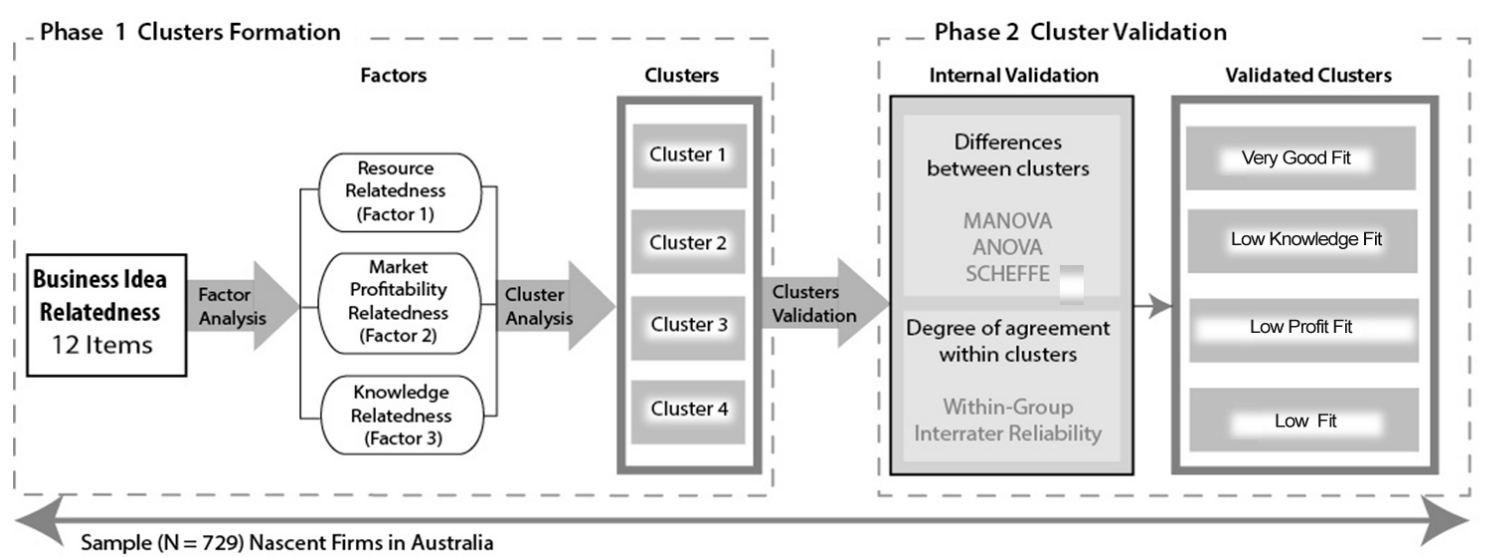

Figure 1. Cluster formation and cluster validation.

First, in Phase 1 the 12 items reflecting the business idea relatedness (See Table 2) are factors analyzed in order to identify possible factors that summarize the main possible types of activities that a firm could engage in. This is done to ensure that the items accurately reflect the scales of knowledge relatedness, profitability relatedness and resource relatedness.

Once the factors were identified, the computed results for each factor were used in a cluster analysis in order to cluster firms based on their preferences around the different types of innovative activities. As this was an exploratory study, no a priori number of clusters were expected, different cluster solutions are tested empirically and theoretically. The four cluster structure was chosen due to its strong internal consistency and significant external differences.

In Phase 2, this study used two main tools to validate the four clusters: the first was evidence of high external heterogeneity and the second was high internal homogeneity [87]. External heterogeneity involves measuring the differences between the four clusters in relation to the three business idea relatedness factors to see if there are significant differences between them. Manova, Anova and Scheffe analyses were used for this purpose. Internal homogeneity shows the degree of agreement between managers within each cluster in relation to the degree of influence that the eight factors played on their decision-making process. The within-group interrater reliability test was used for this purpose [88]. 
Table 2. Survey questions.

\begin{tabular}{|c|c|}
\hline & Knowledge Relatedness \\
\hline A & $\begin{array}{l}\text { The PRODUCT/SERVICE offerings are selected so that they are very closely matched with the } \\
\text { knowledge and skills that you already had }\end{array}$ \\
\hline $\mathrm{B}$ & $\begin{array}{l}\text { The customers or target markets are selected so that they are very closely matched with the knowledge } \\
\text { and skills that you already had }\end{array}$ \\
\hline $\mathrm{C}$ & $\begin{array}{l}\text { The methods for producing or sourcing are selected so that they are very closely matched with the } \\
\text { knowledge and skills that you already had }\end{array}$ \\
\hline \multirow[t]{2}{*}{$\mathrm{D}$} & $\begin{array}{l}\text { The methods for promotion and selling are selected so that they are very closely matched with the } \\
\text { knowledge and skills that you already had }\end{array}$ \\
\hline & Profitability Relatedness \\
\hline $\mathrm{E}$ & $\begin{array}{l}\text { The PRODUCT/SERVICE offerings are selected because they represent the most profitable opportunities } \\
\text { that exist in the market }\end{array}$ \\
\hline $\mathrm{F}$ & $\begin{array}{l}\text { The customers or target markets are selected because they represent the most profitable opportunities that } \\
\text { exist in the market }\end{array}$ \\
\hline G & $\begin{array}{l}\text { The methods for producing or sourcing are selected because they represent the most profitable } \\
\text { opportunities that exist in the market }\end{array}$ \\
\hline \multirow[t]{2}{*}{$\mathrm{H}$} & $\begin{array}{l}\text { The methods for promotion and selling are selected because they represent the most profitable } \\
\text { opportunities that exist in the market closely match the financial, physical and other resources you have } \\
\text { access to }\end{array}$ \\
\hline & Resource Relatedness \\
\hline I & $\begin{array}{l}\text { The PRODUCT/SERVICE offerings are selected to very closely match the financial, physical and other } \\
\text { resources you have access to }\end{array}$ \\
\hline $\mathrm{J}$ & $\begin{array}{l}\text { The customers or target markets are selected to very closely match the financial, physical and other resources } \\
\text { you have access to }\end{array}$ \\
\hline K & $\begin{array}{l}\text { The methods for producing or sourcing are selected to very closely match the financial, physical and other } \\
\text { resources you have access to }\end{array}$ \\
\hline $\mathrm{L}$ & $\begin{array}{l}\text { The methods for promotion and selling are selected to very closely match the financial, physical and other } \\
\text { resources you have access to }\end{array}$ \\
\hline
\end{tabular}

\section{Results}

This section shows the results of the factor analysis and the cluster analysis. As a result of the factor analysis, three factors were identified (see Table 3). The cluster analysis was then performed on the computed results from the factor analysis.

Next, using the factors identified, the cluster analysis was conducted. Table 4 provides four cluster solutions for the cluster analysis performed on the three factors identified in Table 3 (loading resource relatedness, loading profitability relatedness, loading knowledge relatedness).

Cluster 1 , which represents $43 \%$ of the sample (304), performed as follows in relation to the three factors: 4.8 resource relatedness, 4.6 profitability relatedness and 4.7 knowledge relatedness.

Cluster 2, which represents $24 \%$ of the sample (178), performed as follows in relation to the three factors: 4.3 resource relatedness, 4.3 profitability relatedness and 3.7 knowledge relatedness.

Cluster 3 , which represents $22 \%$ of the sample (167), performed as follows in relation to the three factors: 4.2 resource relatedness, 2.7 profitability relatedness and 4.3 knowledge relatedness.

Cluster 4 , which represents $11 \%$ of the sample (80) performed as follows in relation to the three factors: 2.3 resource relatedness, 3.7 profitability relatedness and 3.3 knowledge relatedness.

To test for overall multivariate differences, a MANOVA (Multivariate Analyses of Variance) procedure was used to show that the four clusters were significantly different $(\mathrm{F}=1.348$ and $p<0.001)$. Variations in the dimensions of the three factors among the four clusters were gleaned from ANOVA (Analysis Of Variance), as summarized in Table 4. Scheffe tests also highlighted the distinguishing qualities of the four clusters. In reviewing the clusters, the reader should note that because the number and content of clusters were inseparable from the classification criteria used, the results of the ANOVA are presented only to illustrate where the greatest differences existed among the clusters. 
Table 3. Factor analysis of business idea relatedness (12 items).

\begin{tabular}{|c|c|c|c|}
\hline $\begin{array}{c}\text { Items } \\
\text { Business Idea Relatedness ... }\end{array}$ & $\begin{array}{c}\text { Factors 1 } \\
\text { Loading } \\
\text { Resource Relatedness } \\
\end{array}$ & $\begin{array}{c}\text { Factors 2 } \\
\text { Loading } \\
\text { Profitability Relatedness } \\
\end{array}$ & $\begin{array}{c}\text { Factors } 3 \\
\text { Loading } \\
\text { Knowledge Relatedness }\end{array}$ \\
\hline ... product related to knowledge and skills & 0.117 & 0.039 & 0.749 \\
\hline ... customer or target market related to knowledge and skills & 0.197 & 0.069 & 0.671 \\
\hline ... production methods related to knowledge and skills & 0.124 & 0.070 & 0.783 \\
\hline ... promotion methods related to knowledge and skills & 0.127 & 0.191 & 0.644 \\
\hline ... product represents most profitable opportunity & 0.126 & 0.776 & 0.074 \\
\hline ... customer or target market represents most profitable opportunity & 0.130 & 0.832 & 0.096 \\
\hline ... production methods represent most profitable opportunities & 0.189 & 0.770 & 0.086 \\
\hline ... represents the most profitable opportunities & 0.150 & 0.730 & 0.130 \\
\hline$\ldots$ product matches own resources & 0.781 & 0.184 & 0.144 \\
\hline ... customer or target market matches own resources & 0.797 & 0.126 & 0.210 \\
\hline ... production methods matches own resources & 0.826 & 0.149 & 0.159 \\
\hline ... promotion method matches own resources & 0.765 & 0.175 & 0.137 \\
\hline Cronbach's Alpha & 0.719 (4 items) & 0.811 (4 items) & $0.842(4$ items $)$ \\
\hline
\end{tabular}

Table 4. Cluster analysis results, ANOVA and James agreement test.

\begin{tabular}{|c|c|c|c|c|c|c|c|}
\hline Factors & $\begin{array}{l}\text { Cluster } 1 \\
(\mathrm{~N}=304)\end{array}$ & $\begin{array}{l}\text { Cluster } 2 \\
(\mathrm{~N}=178)\end{array}$ & $\begin{array}{l}\text { Cluster } 3 \\
(\mathrm{~N}=167)\end{array}$ & $\begin{array}{l}\text { Cluster } 4 \\
(\mathrm{~N}=80)\end{array}$ & Scheffe Results & $\mathbf{F}$ & Sig. \\
\hline $\begin{array}{c}\text { Factors } 1 \\
\text { Resource Relatedness }\end{array}$ & 4.7656 & 4.2893 & 4.2231 & 2.3271 & $1 \& 2,2 \& 3,1 \& 4$, and $2 \& 4$ & 554.5 & 0.000 \\
\hline $\begin{array}{c}\text { Factor } 2 \\
\text { Profitability Relatedness }\end{array}$ & 4.5543 & 4.2734 & 2.7440 & 3.2688 & $1 \& 2,2 \& 3$, and 13 & 350.1 & 0.000 \\
\hline $\begin{array}{c}\text { Factor } 3 \\
\text { Knowledge Relatedness }\end{array}$ & 4.7196 & 3.6484 & 4.2560 & 3.3219 & $1 \& 2,2 \& 3$, and $1 \& 3$ & 179.1 & 0.000 \\
\hline James test of internal interrater reliability & $\underline{98 \%}$ & $\underline{97 \%}$ & $\underline{95 \%}$ & $\underline{83 \%}$ & & & \\
\hline
\end{tabular}




\section{Discussion}

This section is structured in two main parts to better describe Figure 2 in detail. The first part discusses the taxonomy and the four clusters that have emerged from the analysis previously described (Figure 2). The second part discusses the importance of firms concentrating on the value co-creation processes to fill the necessary gaps in their business idea to reach the expected overall levels for all the three factors (resource relatedness, profitability relatedness and knowledge relatedness) to provide the foundations for a sustainable business (see Figure 2). The more the business ideas are unfit for the "sustainable business idea" level, the more the entrepreneurs should seek opportunities arising from the relationship between them and their value networks. This is intended as a way to create heightened awareness of the importance of business idea relatedness and business sustainability.

We begin this discussion by providing a quick description of Figure 2, which not only provides a visual interpretation of the four clusters of the business idea taxonomy developed in this paper, but also suggests that to be sustainable any business idea should have access to the necessary factors. As previously mentioned, those factors involve having access to the necessary resources [57], related knowledge [34,89] and profitable market opportunities [15]. This increases the sustainability of a business idea and sub-sequentially the survival of the business. However, not every business idea has been crafted in a way that all those three paramount conditions have been met. Therefore, this section discusses the four clusters in relation to the three pillars for a successful business idea. See Figure 2.

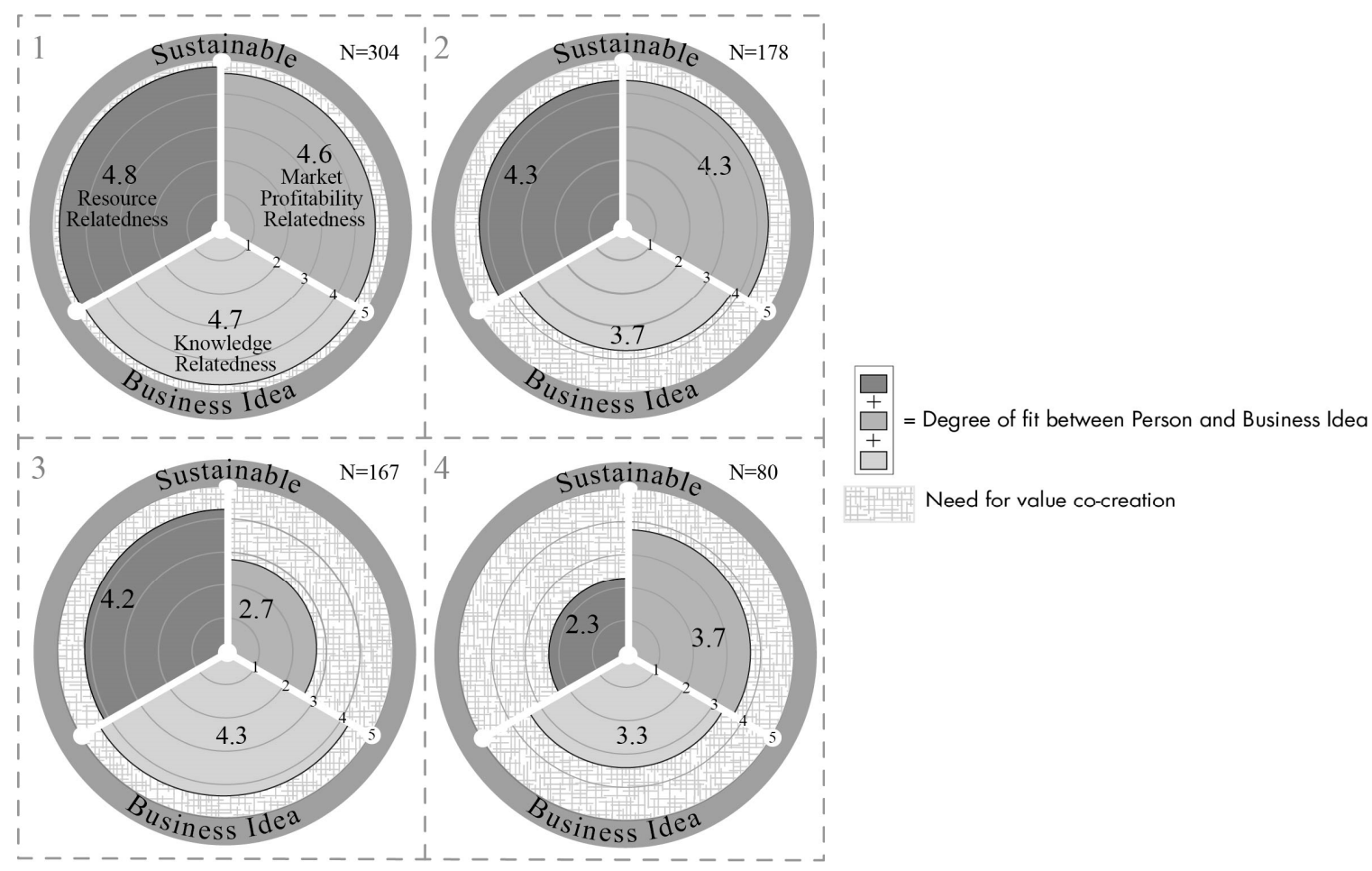

Figure 2. Taxonomy of business idea fit, sustainability and value co-creation.

As previously argued in this paper, the business idea is the first of multiple stages of the developmental process of business sustainability. Therefore, knowing that there are four unique types of business idea fit becomes extremely important to better prepare nascent firms for a sustainable future. As shown in Figure 2, each of the four profiles has corresponding levels of the business idea fit across the three factors marked in multiple shades of grey.

Cluster 1 is the vivid example of best fit between the business idea and the knowledge (4.7) and resources (4.8) available to the creator/entrepreneur plus the market profitability (4.6). This means 
that, not only is the idea in the business area in which the entrepreneur has strong knowledge, and the idea is in accordance with the resources available, but also the business idea is crafted to target the most profitable market opportunity. Thus, we call Cluster 1 firms the high fit cluster.

Cluster 2 has slightly less strong fit in terms of resources available for the business venture idea and also less fit with profitability, but it is weakest in term of matching the knowledge to which the entrepreneur has access. Cluster 2 firms are the low knowledge fit cluster.

While the first two clusters have a good across the board fit, in contrast Cluster 3 has a weaker fit overall but, most importantly, has significantly weaker market profitability fit. We call Cluster 3 the low profit fit cluster.

Similarly, Cluster 4 also has only a moderate overall fit but with a significantly lower resource fit. We call Cluster 4 the low fit cluster.

Thus, this study has made a contribution by identifying four distinct clusters of start-up strategies in term of their new business idea relatedness.

However, what has not been discussed yet is the area showing the lack of fit (hashed area) between the person/entrepreneur and the venture idea (Figure 2). What that area highlights are the mismatches between the nascent business and a good business idea to provide the best initial step for the future sustainability of that business. This lack of fit provides an opportunity for value co-creation. As a result, it is clear that Cluster 4 represents an example of business ideas that most require external support, mostly for resources (resource relatedness 2.7) but also in terms of both market profitability (3.7) and knowledge relatedness (3.3). Similarly, but less evidently, Cluster 2 needs more support in terms of knowledge (3.7) and Cluster 3 needs better market profitability (2.7).

As previously mentioned, sustainability involves the necessity to preserve resources or at least to use them parsimoniously. Therefore it is evident from this study that not all business ideas (clusters) are in the same position (fit) with the necessary resources to ensure a sustainable business venture. Thus, for those business ideas that are not well-fitted, it is necessary to interact with other parties to improve their fit and support a sustainable future. For example, the least fitting business idea is Cluster 4, which to be sustainable requires strong external support in terms of resources, medium knowledge support and improved market profitability. On the other hand, Cluster 1 is the best fit of all with a possible opportunity to improve market profitability and perhaps optimize their resources and advance their current knowledge. In this cluster the business must be focused on how to maintain and improve their policy and strategy under the lens of sustainability in the direction of value cocreation. For the remaining two clusters, one requires a strong attention with relation to knowledge (Cluster 2) and the other requires attention to market profitability (Cluster 3).

Finally, nascent firms need to have a clear knowledge of which customers need to be addressed and what knowledge and resources are to be fielded to grasp the chosen market opportunity. The nascent firm needs to be aware of all the opportunities and this can be determined by the type of clusters identified in this paper. Depending on the type of cluster and according to Nenonen and Storbacka [18], the degree of exchange of resources with the other actors in the value network can be realized. Value can be co-created "collaboratively in interactive configurations of mutual exchange" [65] (p. 145). These two theoretical aspects can concretely support the nascent firms in fitting the business idea to the knowledge, resources and market profitability in order to be sustainable by co-creating value within their network to regenerate itself over time through the sharing of economic and social value.

\section{Conclusions and Limitations}

In conclusion, sustainability is the result of a developmental process that requires that the business idea, which may take different forms based on the gap between the resources brought by the entrepreneur, and the necessary value co-creation strategy used to fill that gap. The business idea represents the first step into the development of a sustainable business. We found four distinct clusters of nascent firms, which were distinguished by the fit of their new business ideas to the owner's knowledge, resources and market profitability: The very good fit, low knowledge fit, low profit fit and 
low fit. Depending on the fit degree of the relatedness (resource, knowledge and market profitability) shown in each cluster, the sustainability of a business idea can be improved, ensuring sustainability by activating a value cocreation process through a win-win type interaction with other actors.

The taxonomy emerging form this study can be useful in different ways. Firstly, entrepreneurs can use the four clusters as a self-assessment to understand and maximize the degree of business idea fit through activating relationships with other actors to co-create value. Secondly, consultants can use the taxonomy to support future entrepreneurs guiding them towards a sustainability more linked to business survival. Thirdly, the taxonomy can be used in teaching activities relating to business start-ups and business idea fit, helping the students to understand the importance of strategic collaborations to improve business sustainability and survival.

Future research is needed to identify the antecedents and the impact of sustainability on each of the four clusters. Due to the fact that this study is limited to Australia, it should be replicated in other countries to further validate the reliability and validity of the model tested in this paper.

Finally, future research should concentrate on identifying the necessary steps from building the business idea to achieving a sustainable firm.

Author Contributions: Although the paper is the result of synergic work, Sections 4-5 are attributed to Gian Luca Casali; Section 1, Section 2.1, and Section 6 to Mirko Perano; Section 2, Section 2.2, and Section 2.3 to Andrea Moretta Tartaglione; and the abstract; Section 3, Section 7 and in addition the language and final revisions to Roxanne Zolin.

Conflicts of Interest: The authors declare no conflict of interest.

\section{References}

1. Driver, M. An Interview with Micheal Porter: Social Entrepreneurship and the Transformation of Capitalism. Acad. Manag. Learn. Educ. 2012, 11, 421-431. [CrossRef]

2. Williamson, O. Corporate Governance. Yale Law J. 1984, 93, 1197-1230. [CrossRef]

3. Jensen, M.C. Non-rational behavior, value conflicts, stakeholder theory, and firm behavior. Bus. Ethics Q. 2008, 18, 167-171. [CrossRef]

4. Porter, M.E.; Kramer, M.R. Strategy and Society: The Link between Competitive Advantage and Corporate Social Responsibility. Harv. Bus. Rev. 2006, 84, 78-92. [CrossRef] [PubMed]

5. Dawson, P.; Daniel, L. Understanding social innovation: A provisional framework. Int. J. Technol. Manag. 2010, 51, 9-21. [CrossRef]

6. Martins, T.C.M.; de Souza Bermejo, P.H. Open Social Innovation. In Handbook of Research on Democratic Strategies and Citizen-Centered E-Government Services; IGI Global: Hershey, PA, USA, 2015; pp. 144-163; ISBN 13: 9781466684683.

7. European Union. Social Innovation. 2015. Available online: https://ec.europa.eu/growth/industry/ innovation/policy/social_en (accessed on 12 October 2017).

8. Hopwood, B.; Mellor, M.; O’Brien, G. Sustainable Development: Mapping Different Approaches. Sustain. Dev. 2005, 13, 38-52. [CrossRef]

9. Elkington, J. Cannibals with Forks-The Triple Bottom Line of 21st Century Business; Capstone Publishing Ltd.: Oxford, UK, 1997.

10. Elkington, J. Governance for sustainability. Corp. Gov. 2006, 14, 522-529. [CrossRef]

11. Kuckerts, A.; Wagner, M. The influence of sustainability orientation on entrepreneurial intentions-Investigating the role of business experience. J. Bus. Ventur. 2010, 25, 524-539. [CrossRef]

12. Hawken, P. The Ecology of Commerce: A Declaration of Sustainability; Harper Business: New York, NY, USA, 1993.

13. Viederman, S. Public policy: Challenge to ecological economic. In Investing in Natural Capital: The Ecological Economics Approach to Sustainability; Jansson, A., Hammer, M., Folke, C., Costanza, R., Eds.; Island Press: Washington, DC, USA, 1994; pp. 467-478.

14. Davidsson, P. Researching Entrepreneurship; Springer: New York, NY, USA, 2004.

15. Witell, L.; Kristensson, P.; Gustafsson, A.; Löfgren, M. Idea generation: Customer co-creation versus traditional market research techniques. J. Serv. Manag. 2011, 22, 140-159. [CrossRef] 
16. Vargo, S.L.; Lusch, R.F. Evolving to a new dominant logic for marketing. J. Mark. 2004, 68, 1-17. [CrossRef]

17. Vargo, S.L.; Lusch, R.F. Service-dominant logic: Continuing the evolution. J. Acad. Mark. Sci. 2008, 36, 1-10. [CrossRef]

18. Nenonen, S.; Storbacka, K. Business model design: Conceptualizing networked value co-creation. Int. J. Q. Serv. Sci. 2010, 2, 43-59. [CrossRef]

19. Vargo, S.L.; Lusch, R.F. Institutions and axioms: An extension and update of service-dominant logic. J. Acad. Mark. Sci. 2016, 44, 5-23. [CrossRef]

20. Al-Debei, M.M.; El-Haddadeh, R.E.; Avison, D. Defining the Business Model in the New World of Digital Business. In Proceedings of the Americas Conference on Information Systems, Toronto, ON, Canada, 14-17 August 2008.

21. Hamel, G. Leading the Revolution; Harvard Business School Press: Boston, MA, USA, 2000.

22. Voelpel, S.C.; Leibold, M.; Tekie, E.B. The wheel of business model reinvention: How to reshape your business model to leapfrog competitors. J. Chang. Manag. 2004, 4, 259-276. [CrossRef]

23. Zott, C.; Amit, R. The fit between product market strategy and business model: Implications for firm performance. Strateg. Manag. J. 2008, 29, 1-26. [CrossRef]

24. Storbacka, K.; Frow, P.; Nenonen, S.; Payne, A. Designing Business Models for Value Co-Creation. In Special Isssue-Toward a Better Understanding of the Role of Value in Markets and Marketing Research; Vargo, S.L., Lusch, R.F., Eds.; Emerald Group Publishing: Bingley, UK, 2012; pp. 51-78.

25. Semasinghe, D.M.; Davidsson, P.; Steffens, P.R. Nascent venture performance: Linking novelty of venture ideas and commitment of firm founders as predictors. In Proceedings of the 8th AGSE International Entrepreneurship Research Exchange, Melbourne, Australian, 1-4 February 2011; Maritz, A., Ed.; Swinburne University of Technology: Melbourne, Australia; pp. 597-607.

26. Shane, S.; Venkataraman, S. The Promise of Entrepreneurship as a Field of Research. Acad. Manag. Rev. 2000, 25, 217-226. [CrossRef]

27. Semasinghe, D.M. The Role of Idea Novelty and Relatedness on Venture Performance. Ph.D. Thesis, Business School, Queensland University of Technology, Brisbane, Australia, February 2011.

28. Davis, P.S.; Robinson, R.B., Jr.; Pearce, J.A., II; Park, S.H. Business Unit Relatedness and Performance: A Look at the Pulp and Paper Industry. SMJ 1992, 13, 349-362. [CrossRef]

29. Farjoun, M. The Independent and Joint Effects of The Skill and Physical Bases of Relatedness in Diversification. Strateg. Manag. J. 1998, 19, 611-630. [CrossRef]

30. Lampert, C.M. Learning and Corporate Evolution: A Longitudinal Study of How Product-Market Relatedness and Environmental Relatedness Impact Firm Scope. Ph.D. Thesis, Degree of Doctor of Philosophy. Faculty of the Graduate School, University of Texas at Austin, Austin, TX, USA, August 2003. Available online: https:/ / repositories.lib.utexas.edu/bitstream/handle/2152/418/lampertcm036.txt? sequence $=3$ (accessed on 10 October 2017).

31. D'Aveni, R.A.; Ravenscraft, D.J.; Anderson, P. From corporate strategy to business-level advantage: Relatedness as resource congruence. Manag. Decis. Econ. 2004, 25, 365-381. [CrossRef]

32. Pehrsson, A. Business relatedness measurements. Eur. Bus. Rev. 2006, 18, 350-363. [CrossRef]

33. Cooper, A.C.; Folta, T.B.; Woo, C.Y. Entrepreneurial information search. J. Bus. Ventur. 1995, 10, $107-120$. [CrossRef]

34. Fiet, J.O. Entrepreneurial Competence as Knowledge; Jönköping International Business School: Jönköping, Sweden, 1999.

35. Shane, S. Prior knowledge and the discovery of entrepreneurial opportunities. Organ. Sci. 2000, 11, 448-469. [CrossRef]

36. Chandler, G.N.; Hanks, S.H. Market attractiveness, resource-based capabilities, venture strategies, and venture performance. J. Bus. Ventur. 1994, 9, 331-349. [CrossRef]

37. Rogers, E.M. Diffusion of Innovations, 4th ed.; The Free Press: New York, NY, USA, 1995.

38. Normann, R. Management for Growth; Wiley: Chichester, UK, 1977.

39. Normann, R. Reframing Business: When the Map Changes the Landscape; Wiley: Chichester, UK, 2001.

40. Hedman, J.; Kalling, T. The business model concept: Theoretical underpinnings and empirical illustrations. Eur. J. Inf. Syst. 2003, 12, 49-59. [CrossRef]

41. Zott, C.; Amit, R. Business Model Design and the Performance of Entrepreneurial Firms. Organ. Sci. 2007, 18, 181-199. [CrossRef] 
42. Frow, P.; Payne, A. A stakeholder perspective of the value proposition concept. Eur. J. Mark. 2011, 45, 223-240. [CrossRef]

43. Bollinger, A.S.; Smith, R.D. Managing organizational knowledge as a strategic asset. J. Knowl. Manag. 2001, 5, 8-18. [CrossRef]

44. Berger, P.L.; Luckmann, T. The Social Construction of Reality: A treatIse in the Sociology of Knowledge; Penguin: London, UK, 1967.

45. Hunt, S.D. A General Theory of Competition: Resources, Competences, Productivity, Economic Growth; Sage Publications: Thousand Oaks, CA, USA, 2000.

46. Lusch, R.F.; Vargo, S.L.; O’Brien, M. Competing through service: Insights from service-dominant logic. J. Retail. 2007, 83, 5-18. [CrossRef]

47. Zhang, X.; Chen, R. Examining the mechanism of the value co-creation with customers. Int. J. Product. Econ. 2008, 116, 242-250. [CrossRef]

48. Maglio, P.P.; Spohrer, J. Fundamentals of service science. J. Acad. Mark. Sci. 2008, 36, 18-20. [CrossRef]

49. Enz, M.G.; Lambert, D.M. Using cross-functional, cross-firm teams to co-create value: The role of financial measures. Ind. Mark. Manag. 2012, 41, 495-507. [CrossRef]

50. Grover, V.; Kohli, R. Co-creating IT value: New capabilities and metrics for multifirm environments. MIS $Q$. 2012, 36, 225-232.

51. Powell, J.H.; Swart, J. Mapping the values in B2B relationships: A systemic, knowledge-based perspective. Ind. Mark. Manag. 2010, 39, 437-449. [CrossRef]

52. Ramirez, R. Value co-production: Intellectual origins and implications for practice and research. Strateg. Manag. J. 1999, 20, 49-65. [CrossRef]

53. Fisher, D.; Smith, S. Co-creation is chaotic: What it means for marketing when no one has control. Mark. Theory 2011, 11, 325-350. [CrossRef]

54. Wiklund, J.; Shepherd, D.A. Knowledge-Based Resources, Entrepreneurial Orientation, and the Performance of Small and Medium-Sized Businesses. SMJ 2003, 24, 1307-1314. [CrossRef]

55. Tanriverdi, H.; Venkatraman, N. Knowledge Relatedness and the Performance of Multibusiness Firms. Strateg. Manag. J. 2005, 26, 97-119. [CrossRef]

56. West, G.P.; Noel, T.W. The impact of knowledge resources on new venture performance. J. Small Bus. Manag. 2009, 47, 1-22. [CrossRef]

57. Kirzner, I.M. Competition and Entrepreneurship; University of Chicago Press: Chicago, IL, USA, 1973.

58. Katz, J.; Gartner, W.B. Properties of Emerging Organizations. Acad. Manag. Rev. 1988, 13, 429-441. [CrossRef]

59. Brush, C.G.; Greene, P.G.; Hart, M.M. From initial idea to unique advantage: The entrepreneurial challenge of constructing a resource base. Acad. Manag. Exec. 2001, 15, 64-78. [CrossRef]

60. Arnould, E.J. Service-dominant logic and resource theory. J. Acad. Mark. Sci. 2008, 36, 21-24. [CrossRef]

61. Lusch, R.F.; Vargo, S.L. Service dominant logic as a foundation for a general theory. In The Service-Dominant Logic of Marketing: Dialog, Debate, and Directions; Lusch, R.F., Vargo, S.L., Eds.; ME Sharpe: Armonk, NY, USA, 2006; pp. 251-265.

62. Storbacka, K.; Nenonen, S.; Korkman, O. Markets as Configurations: A Research Agenda for Cocreated Markets; Working Paper; Nyenrode Business Universiteit: Breukelen, The Netherlands, 2009.

63. Vargo, S.L. On a theory of markets and marketing: From positively normative to normatively positive. Australas. Mark. J. 2007, 15, 53-60. [CrossRef]

64. Storbacka, K.; Brodie, R.J.; Böhmann, T.; Maglio, P.P.; Nenonen, S. Actor engagement as a microfoundation for value co-creation. J. Bus. Res. 2016, 69, 3008-3017. [CrossRef]

65. Vargo, S.L.; Maglio, P.P.; Akaka, M.A. On value and value co-creation: A service systems and service logic perspective. Eur. Manag. J. 2008, 26, 145-152. [CrossRef]

66. Frow, P.; McColl-Kennedy, J.R.; Hilton, T.; Davidson, A.; Payne, A.; Brozovic, D. Value propositions: A service ecosystems perspective. Mark. Theory 2014, 14, 327-351. [CrossRef]

67. Merz, M.A.; He, Y.; Vargo, S.L. The evolving brand logic: A service dominant logic perspective. J. Acad. Mark. Sci. 2009, 37, 328-344. [CrossRef]

68. Vargo, S.L.; Lusch, R.F. It's all B2B ... and beyond: Toward a systems perspective of the market. Ind. Mark. Manag. 2011, 40, 181-187. [CrossRef]

69. Hunt, S.D.; Derozier, C. The normative imperatives of business and marketing strategy: Grounding strategy in resource advantage theory. J. Bus. Ind. Mark. 2004, 19, 5-22. [CrossRef] 
70. Wernerfelt, B. A resource-based view of the firm. Strateg. Manag. J. 1984, 5, 171-180. [CrossRef]

71. Barreto, I. A behavioral theory of market expansion based on the opportunity prospects rule. Organ. Sci. 2012, 23, 1008-1023. [CrossRef]

72. Plumly, L.W., Jr.; Marshall, L.L.; Eastman, J.; Iyer, R.; Stanley, K.L.; Boatwright, J. Developing entrepreneurial competencies: A student business. J. Entrep. Educ. 2008, 11, 17-28.

73. Anker, T.B.; Sparks, L.; Moutinho, L.; Grönroos, C. Consumer dominant value creation: A theoretical response to the recent call for a consumer dominant logic for marketing. Eur. J. Mark. 2015, 49, 532-560. [CrossRef]

74. Grönroos, C. Value co-creation in service-logic: A critical analysis. Mark. Theory 2011, 11, 279-301. [CrossRef]

75. Payne, A.F.; Storbacka, K.; Frow, P. Managing the co-creation of value. J. Acad. Mark. Sci. 2008, 36, 83-96. [CrossRef]

76. Aarikka-Stenroos, L.; Jaakkola, E. Value co-creation in knowledge intensive business services: A dyadic perspective on the joint problem solving process. Ind. Mark. Manag. 2012, 41, 15-26. [CrossRef]

77. Edvardsson, B.; Tronvoll, B.; Gruber, T. Expanding understanding of service exchange and value co-creation: A social construction approach. J. Acad. Mark. Sci. 2011, 39, 327-339. [CrossRef]

78. Ordanini, A.; Pasini, P. Service co-production and value co-creation: The case for a service-oriented architecture (SOA). Eur. Manag. J. 2008, 26, 289-297. [CrossRef]

79. Burns, T. The comparative study of organizations. In Methods of Organizational Research; Vroom, V.H., Ed.; University of Pittsburgh Press: Pittsburgh, PA, USA, 1967; pp. 113-170.

80. Davidsson, P. Entrepreneurship-And after? A study of growth willingness in small firms. J. Bus. Ventur. 1989, 4, 211-226. [CrossRef]

81. Rich, V. Code on medical ethics divides Poland's doctors. New Sci. 1992, 133, 13.

82. Archibugi, D. Pavitt's taxonomy sixteen years on: A review article. Econ. Innovat. New Technol. 2001, 10, 415-425. [CrossRef]

83. De Jong, J.P.; Marsili, O. The fruit flies of innovations: A taxonomy of innovative small firms. Res. Policy 2006, 35, 213-229. [CrossRef]

84. Ketchen, D.J.; Shook, C.L. The application of cluster analysis in strategic management research: An analysis and critique. Strateg. Manag. J. 1996, 17, 441-458. [CrossRef]

85. Sabherwal, R.; Robey, D. Reconciling variance and process strategies for studying information system development. Inf. Syst. Res. 1995, 6, 303-327. [CrossRef]

86. Davidsson, P.; Steffens, P.R.; Gordon, S.R.; Reynolds, P. Anatomy of New Business Activity in Australia: Some Early Observations from the CAUSEE Project. In School of Management Technical Report, Faculty of Business; Queensland University of Technology: Brisbane, Australia, 2008.

87. Hair, J.F., Jr.; Babin, B.; Money, A.H.; Samouel, P. Essential of Business Research Methods; Wiley: Hoboken, NJ, USA, 2003.

88. James, L.R.; Memaree, R.G.; Wolf, G. An assessment of within-group interrater agreement. J. Appl. Psychol. 1993, 78, 306-309. [CrossRef]

89. Ronstadt, R. The Corridor Principle. J. Bus. Ventur. 1988, 3, 31-40. [CrossRef]

(C) 2018 by the authors. Licensee MDPI, Basel, Switzerland. This article is an open access article distributed under the terms and conditions of the Creative Commons Attribution (CC BY) license (http://creativecommons.org/licenses/by/4.0/). 